Research Article

\title{
Bird Diversity and Community Composition in Kafta Sheraro National Park, Tigray, Northern Ethiopia
}

\author{
Teklay Girmay $\mathbb{D}^{\mathrm{D}}$, Zeyede Teshome, and Tesfay Tesfamichael \\ Department of Biology, Adigrat University, P. O. Box 50, Adigrat, Ethiopia \\ Correspondence should be addressed to Teklay Girmay; tekigir9@gmail.com
}

Received 1 October 2019; Revised 19 December 2019; Accepted 27 January 2020; Published 20 February 2020

Academic Editor: Hynek Burda

Copyright ( 92020 Teklay Girmay et al. This is an open access article distributed under the Creative Commons Attribution License, which permits unrestricted use, distribution, and reproduction in any medium, provided the original work is properly cited.

\begin{abstract}
Birds are one of the most important components of biodiversity that has huge ecological, economical, and esthetic values. The main objective of this study was to assess diversity and species composition of bird community in Kafta Sheraro National Park, Northern Ethiopia. Data were collected from August 2017 to March 2018 in the national park. Point count method was employed to collect data on bird species diversity and species composition. Direct observations of birds and discussion with local people and scouts to assess potential threats of avifauna in the park were made. Shannon diversity index was used to calculate the species diversity. A total of 158 bird species belonging to 52 different families and 20 orders were identified. Of the recorded species, there were $76.6 \%$ residents, $15.8 \%$ Palaearctic migrants (PM), 5.7\% Intra-African migrants (IM), and 1.9\% partial migrants. Accipitiridae (11.4\%) had the highest species followed by Columbidae, Estrilidae, and Ploceidae with 7\%, 5.7\%, and 4.4\% species, respectively. The highest Shannon-Weiner diversity index $\left(H^{\prime}=4.50\right)$ was recorded during February while the lowest $\left(H^{\prime}=2.18\right)$ was recorded during March. Species richness of the park showed no significance difference among the study months $\left(\chi^{2}=10.046\right.$, $\mathrm{d} f=5, P>0.05)$. Agricultural expansions, fire, livestock grazing, mining, and poaching were the major threats of the park bird species. Kafta Sheraro National Park is one of the areas with high avian composition in Ethiopia. In the park, wildlife watching in general and ornithological tourism in particular should be developed. Anthropogenic disturbances should also be minimized to conserve avian diversity of the park.
\end{abstract}

\section{Background}

Ethiopia possesses many designated protected areas including national parks, sanctuaries, priority forests, and biosphere reserves. High numbers of biodiversity are found within these conservation areas [1]. Ethiopia is endowed with great diversity of flora, fauna, and microbial genetic resources. The country is one of biodiversity-rich countries in the world. According to Lepage [2], Ethiopia is known to be home for 864 species of birds with 19 endemism. In addition, the number of mammals, reptile, fish, amphibian, and arthropod species identified so far is $284,201,200,63$, and 1,225 , respectively. Of these faunal resources, 29 wild mammals, 10 reptiles, 40 fishes, 25 amphibians, and 7 arthropod species are endemic to the country [3]. Birds are one of the most important components of biodiversity with huge ecological, economical, and esthetic values. Fruit-eating birds help in dispersal of seeds. Some birds help in production of nectars and used as source of food in different parts of the world. They also serve as indicators of environmental conditions $[4,5]$.

Wildlife tourism is one of the key economic activities for countries that have rich biodiversity and high endemism [6]. Economic value of wildlife watching tourism is particularly important. Accordingly, wildlife watching in general and bird watching in particular are the most practiced type of the people's income in many African countries [7]. Bird watching is becoming a new area of tourism. It is currently developing and generating significant economic benefit in different countries [8]. Countries which are benefiting from bird watching are those who have documented the necessary information on their ornithological studies. Ornithological knowledge helps to know the locations or distributions of the birds, their diversity, and to analyze the impact of direct 
and indirect effects of tourism on biodiversity [9]. However, no study has assessed the diversity and species composition of the avifauna of Kafta Sheraro National Park. As a result, only few international tourists are visiting it unlike the other Ethiopian National Parks although the national park contains great biodiversity including birds. Therefore, it is expected that this project will help to develop bird-watching tourism of the park.

Kafta Sheraro National Park (KSNP) is a newly established park in Tigray province, Ethiopia. Accordingly, it has little ecological information. Preliminary wildlife assessment of the park showed that the park is rich in faunal diversity. For instance, caracal (Felis caracal), leopard (Panthera pardus), greater kudu (Tragelaphus strepsiceros), oribi (Ourebia ourebi), waterbuck (Kobus ellipsiprymnus), aardvark (Orycteropus afer), roan antelope (Hippotragus equi$n u s$ ), and the African elephant (Loxodonta africana) are some of the larger mammals known in this area [10]. It is also believed that the park contains different unidentified aquatic and terrestrial bird species [11]. Information about avian diversity and abundance is very important for attracting local and international tourists and for conservation of the species. However, no study has been conducted to investigate the diversity and relative abundance of avian species of Kafta Sheraro National Park (KSNP). Thus, this study aims to investigate the diversity and species composition of avian diversity in the national park.

\section{Materials and Methods}

2.1. Description of the Study Area. Kafta Sheraro National Park (KSNP), which was recognized as a park in 2007 (Letter, No: $13 / 37 / 82 / 611$ ), is situated in the northwest of Ethiopia between $14^{\circ} 3^{\prime}$ and $14^{\circ} 27^{\prime} \mathrm{N}$ and $36^{\circ} 41^{\prime}$ and $37^{\circ} 40^{\prime} \mathrm{E}$. It is located in West and North West zones of the Regional State of Tigray, Ethiopia. It is found between Kafta Humera, Tahtay Adiyabo, and Welkayit woredas. The national park is bordered by Eritrea in the north, and it is presumed to have an estimated total area of $2176.43 \mathrm{~km}^{2}$ (Figure 1). It is the only national park in Tigray Regional State, and it is about $1015 \mathrm{~km}$ away from Addis Ababa. Its altitude ranges from 550 to 1800 masl. The agroclimatic zone is identified as Qolla with an inclination to semiarid. Vegetation communities within the park include Acacia-Commiphora, CombretumTerminalia, dry evergreen montane woodlands, and riparian types. The site has a monomodal pattern of rain with high peaks in May and early September with a mean annual rainfall of about $400-650 \mathrm{~mm}$. The park is home to many ungulates, predators, and other wild animal species. The presence of some mega wild animals such as the African elephant, roan antelope, and the cranes (which use the area as a wintering site), and other migratory birds make the park, and its environs a significant site for national and international tourists. Other mammals such as greater kudus and bohor reedbucks are relatively common. The avifauna of the park is rather immense. As a result, the park is registered as one of the 73 important bird areas in Ethiopia. The brown-headed parrot, Parakeet, little green bee-eater, and demoiselle crane are of the few most attractive bird species of the park [11].

2.2. Data Collection. Before collecting the actual data, pilot survey was conducted in the study area in order to have baseline information on the ecology, threats, and bird species of the national park and to decide on the survey design and sampling strategy.

Data collection was carried out from August 2017 to March 2018. Field survey was conducted to study the avian species composition and diversity. A stratified random sampling technique based on the habitat type was used for selecting the actual sites for sampling using point count [12]. The sampling unit within the habitat was determined and assigned on the basis of the area coverage and vegetation type. Bird species were observed using naked eyes and field binoculars for better identification [13]. GPS was used to locate the points for the bird-counting methods. Birds were surveyed using point count technique which is a systematic search over a fixed area and/or for a fixed time (5 minutes). This allows the observer to record all the bird species around. Point counts (point transects) are an efficient and inexpensive survey method for determining avian species composition and abundance [14]. A total of sixty point count stations with $30 \mathrm{~m}$ fixed radius apart were established systematically. Observations were made by standing in a series of point count stations and observing $360^{\circ}$ round and gently up to $30 \mathrm{~m}$ radius distance. The point count stations were $300 \mathrm{~m}$ apart to avoid error of double counting [15]. To minimize disturbance during count, a waiting period of 3 to 5 minutes prior to counting was applied. Bird species were identified and enumerated twice a day that is in the early morning (8:30-11:30 hr) and in the late afternoon (9:30-11: $30 \mathrm{hr}$ ) where bird activity was maximum and on days with good weather conditions [16]. Surveys were conducted on foot.

Photographs and videos were captured to count too many birds that were difficult to identify during the field. Bird calls were recorded whenever possible using a tape recorder. Colored field guides such as [17-19] were used for identification and categorization of birds to their respective taxonomic groups. The experiences of park experts were also used in the identification of birds based on different morphological features such as plumage pattern, size, shapes, colour, songs, and calls. Observed species were identified and recorded on the data sheet prepared for that purpose. Observation and discussion with nearby villagers and scouts were made to assess potential threats of the avifauna in the park. The current human activities including livestock incursion, habitat exploitation, and wildlife utilization were closely examined along with the field survey.

2.2.1. Data Analysis. The species diversity of the area was analyzed using Shannon diversity index [20] as follows:

$$
H^{\prime}=-\sum_{i=1}^{S}\{(P i) *(\ln P i)\},
$$



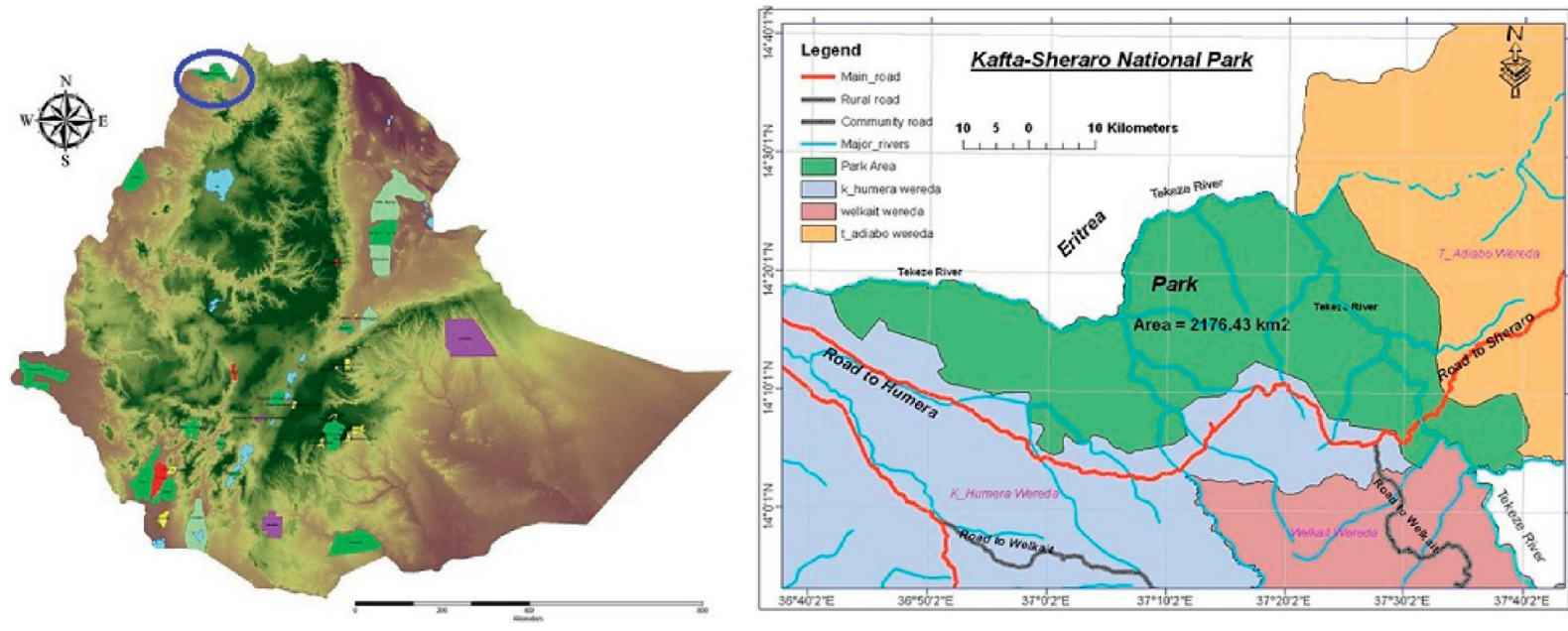

Figure 1: Map showing the location of Kafta Sheraro National Park.

where $H^{\prime}=$ the Shannon diversity index; $P_{i}=$ fraction of the entire population made up of species I; $S=$ numbers of species encountered; $\sum=$ sum from species 1 to species $S$; and $\ln =$ natural logarithm.

Species richness $(S)$ was calculated by

$$
S=\sum n
$$

where $n$ is the number of species in a community.

Species evenness, which measures the pattern of distribution of the bird populations present in the area, was evaluated using Shannon-Wiener evenness index $(E)$ as follows [21]:

$$
E=\frac{H^{\prime}}{H_{\max }}
$$

where $E=$ Shannon-Wiener evenness index; $\mathrm{H}^{\prime}=$ ShannonWiener diversity index; and $H_{\max }=\ln S=$ natural logarithm of the total number of species $(S)$.

Data collected during the study period were analyzed using SPSS software package version 20. Chi-square test was used to test difference of species richness among the study months. Moreover, the collected data were analyzed and interpreted through tabulation and percentage.

\section{Results}

3.1. Species Composition. A total of 158 bird species belonging to 52 different families and 20 orders were identified during the surveys. Of the identified bird species, family Accipitiridae 18 (11.4\%) had the highest species followed by Columbidae, Estrilidae, and Ploceidae with 11 (7\%), 9 (5.7\%), and 7 (4.4\%) number of species, respectively. The lowest number of species was recorded from families Anatidae, Apodidae, Bucorvidae, Burhinidae, Phoeniculidae, Upupidae, Pluvianidae, Numididae, Phasianidae, Leiothrichidae, Monarchidae, Prionopidae, Pycnonotidae, Scopidae, Indicatoridae, Picidae, Strigidae, and Tytonidae with one species each (Table 1). Among the recorded species, 25 (15.8\%), 9 (5.7\%), and 3 (1.9\%) were Palaearctic migrants
(PM), Intra-African migrants (IM), and partial migrants, respectively. The remaining $121(76.6 \%)$ bird species were residents. KSNP is a home to many attractive avian species. A few of them are put in Figure 2.

3.2. Species Diversity, Species Richness, and Species Evenness. The Shannon-Weiner diversity index indicated that the highest diversity of birds $\left(H^{\prime}=4.50\right)$ was recorded during February, and the lowest diversity $\left(H^{\prime}=2.18\right)$ was recorded during March. Similarly, the highest even distribution of birds was observed during February $(E=0.98)$, but the lowest was during March $(E=0.46)$. The majority of species was recorded during January with $131(83 \%)$ species followed by March 108 (68\%) and October 92 (58\%) (Table 2). Species richness of the park showed no significant difference between the study months $\left(\chi^{2}=10.046, \mathrm{~d} f=5, P>0.05\right)$. The wet season diversity index $\left(H^{\prime}=4.6\right)$ was higher than that of the dry season $\left(H^{\prime}=3.2\right)$. Evenness index was also higher during the wet season $(E=0.94)$ than the dry season $(E=0.64)$ (Figure 3).

\section{Discussion}

The result of the current study showed that Kafta Sheraro National Park harbored high diversity $\left(H^{\prime}=2.18\right.$ up to 4.50$)$ and species composition (158 species) because of the ideal habitat condition of the study area for avifauna. This could be due to various vegetation types and weather conditions of the park and location of the Tekeze River along the park. This may provide foraging, breeding, nesting, and other survival opportunities for both aquatic and terrestrial bird species. Moreover, the highest diversity and species composition of avifauna in the park might be due to the situation in which both aquatic and terrestrial bird species inhabit because Tekeze River bounds all parts of the park. This situation may create the park to have high number of aquatic bird species in addition to terrestrial bird species. This study showed that species composition of Kafta Sheraro National Park is highest as compared with other similar studies conducted in 
Table 1: List of bird species recorded in Kafta Sheraro National Park.

\begin{tabular}{|c|c|c|c|c|}
\hline Order & Family & Common name & Scientific name & IUCN status \\
\hline \multirow[t]{18}{*}{ Accipitroformes } & Accipitiridae & Brown snake eagle & Circaetus cinereus & LC \\
\hline & & African fish eagle & Haliaeetus vocifer & $\mathrm{LC}$ \\
\hline & & Long-crested eagle & Laphaetus occipitalis & $\mathrm{LC}$ \\
\hline & & Gabar goshawk & Micronisus gabar & $\mathrm{LC}$ \\
\hline & & Black kite* & Milvus migrans & $\mathrm{LC}$ \\
\hline & & Black-shouldered kite & Elanus caeruleus & LC \\
\hline & & Lappet-faced vulture & Torgos tracheliotos & EN \\
\hline & & Hooded vulture & Necrosyrtes monachus & CR \\
\hline & & African white-backed vulture & Gyps africanus & $\mathrm{CR}$ \\
\hline & & Long-legged buzzard & Buteo rufinus & $\mathrm{LC}$ \\
\hline & & Dark chanting goshawk & Melierax metabates & $\mathrm{LC}$ \\
\hline & & Long-crested eagle & Lophaetus occipitalis & LC \\
\hline & & Tawny eagle & Aquila rapax & VU \\
\hline & & Bateleur & Terathopius ecaudatus & NT \\
\hline & & Steppe eagle & Aquila nipalensis & $\mathrm{EN}$ \\
\hline & & Common buzzard & Buteo buteo & LC \\
\hline & & African cuckoo hawk & Aviceda cuculoides & LC \\
\hline & & African harrier hawk & Polyboroidees typus & LC \\
\hline Anseriformes & Anatidae & Egyptian goose & Alopochen aegyptiaca & $\mathrm{LC}$ \\
\hline Apodiformes & Apodidae & Africa palm swift & Cypsiurus parvus & $\mathrm{LC}$ \\
\hline \multirow[t]{6}{*}{ Bucerotiformes } & Bucerotidae & African grey hornbill & Lophoceros nasutus & LC \\
\hline & & Northern red-billed hornbill & Tockus erythrorhynchus & $\mathrm{LC}$ \\
\hline & & Hemprich's hornbill & Lophoceros hemprichii & LC \\
\hline & Bucorvidae & Abyssinian ground hornbill & Bucorvus abyssinicus & VU \\
\hline & Phoeniculidae & Black-billied wood hoopoe & Phoeniculus somaliensis & $\mathrm{LC}$ \\
\hline & Upupidae & Eurasian hoopoe & Upupa epops & $\mathrm{LC}$ \\
\hline \multirow[t]{2}{*}{ Caprimulgiformes } & Caprimulgidae & Egyptian nightjar & Caprimulgus aegyptius & $\mathrm{LC}$ \\
\hline & & Long-tailed nightjar & Caprimulgus climacurus & LC \\
\hline \multirow{9}{*}{ Charadriiformes } & Burhinidae & Senegal thick-knee & Burhinus senegalensis & LC \\
\hline & Charadriidae & Three-banded plover & Charadrius tricollaris & $\mathrm{LC}$ \\
\hline & & Spur winged lapwing & Vanellus spinosus & LC \\
\hline & & Little-ringed plover & Charadrius dubius & LC \\
\hline & & Black-headed plover & Vanellus tectus & LC \\
\hline & Pluvianidae & Egyptian plover & Pluvianus aegyptius & $\mathrm{LC}$ \\
\hline & Scolopacidae & Common sandpiper ${ }^{\uparrow}$ & Actitis hypoleucos & $\mathrm{LC}$ \\
\hline & & Wood sandpiper & Tringa glareola & LC \\
\hline & & Common greenshank & Tringa nebularia & $\mathrm{LC}$ \\
\hline \multirow[t]{4}{*}{ Ciconiiformes } & Ciconiidae & Abdim's stork* & Ciconia abdimii & LC \\
\hline & & Woolly-necked stork & Ciconia episcopus & VU \\
\hline & & Yellow-billed stork & Mycteria ibis & $\mathrm{LC}$ \\
\hline & & White stork ${ }^{\uparrow}$ & Ciconia ciconia & $\mathrm{LC}$ \\
\hline \multirow[t]{2}{*}{ Coliiformes } & Coliidae & Speckled mousebird & Colius stariatus & $\mathrm{LC}$ \\
\hline & & Blue-naped mousebird & Urocolius macrourus & $\mathrm{LC}$ \\
\hline \multirow[t]{11}{*}{ Columbiformes } & Columbidae & Laughing dove & Stigmatopelia senegalensis & $\mathrm{LC}$ \\
\hline & & Ring naked dove & Streptopelia capicola & LC \\
\hline & & Vinaceous dove & Streptopelia vinacea & LC \\
\hline & & Black-billed wood-dove & Turtur abyssinicus & $\mathrm{LC}$ \\
\hline & & Red-eyed dove & Streptopelia semitorquata & $\mathrm{LC}$ \\
\hline & & Namaqua dove* & Oena capensis & LC \\
\hline & & African mourning dove & Streptopelia decipiens & $\mathrm{LC}$ \\
\hline & & African collared-dove & Streptopelia roseogrisea & $\mathrm{LC}$ \\
\hline & & Emerald-spotted wood dove & Turtur chalcospilos & $\mathrm{LC}$ \\
\hline & & Bruce's green pigeon & Treron waalia & LC \\
\hline & & Speckled pigeon & Columba guinea & $\mathrm{LC}$ \\
\hline \multirow[t]{7}{*}{ Coraciiformes } & Alcedinidae & Giant kingfisher & Megaceryle maxima & $\mathrm{LC}$ \\
\hline & & Pied kingfisher & Ceryle rudis & LC \\
\hline & & Pygmy kingfisher & Ispidina picta & LC \\
\hline & & Mangrove kingfisher & Halcyon senegaloides & $\mathrm{LC}$ \\
\hline & & Malachite kingfisher & Corythornis cristatus & $\mathrm{LC}$ \\
\hline & Coraciidae & Abyssinian roller & Coracias abyssinicus & LC \\
\hline & & Purple roller & Coracias naevius & LC \\
\hline
\end{tabular}


TABle 1: Continued.

\begin{tabular}{|c|c|c|c|c|}
\hline Order & Family & Common name & Scientific name & IUCN status \\
\hline & Meropidae & Blue-breasted Bee-eater* & Merops variegates & LC \\
\hline & & Blue cheeked bee-eater ${ }^{\uparrow}$ & Merops persicus & $\mathrm{LC}$ \\
\hline & & Little bee-eater & Merops pusillus & $\mathrm{LC}$ \\
\hline & & White-throated bee-eater* & Merops albicollis & $\mathrm{LC}$ \\
\hline & & Little green bee-eater & Merops orientalis & $\mathrm{LC}$ \\
\hline & & Northern carmine bee-eater* & Merops nubicus & $\mathrm{LC}$ \\
\hline \multirow[t]{2}{*}{ Cuculiformes } & Cuculidae & White-browed coucal & Centropus superciliosus & $\mathrm{LC}$ \\
\hline & & Blue-headed coucal & Centropus monachus & LC \\
\hline \multirow[t]{3}{*}{ Falconiformes } & Falconidae & Common kestrel $^{\uparrow}$ & Falco tinnunculus & LC \\
\hline & & Grey kestrel & Falco ardosiaceus & LC \\
\hline & & Peregrine falcon & Falco peregrinus & LC \\
\hline \multirow{2}{*}{ Gruiformes } & Gruidae & Common crane & Grus grus & LC \\
\hline & & Demoiselle crane & Anthropoides virgo & LC \\
\hline \multirow[t]{2}{*}{ Galliformes } & Numididae & Helmeted guineafowl & Numida meleagris & LC \\
\hline & Phasianidae & Clapperton's francolin & Pternistis clappertoni & LC \\
\hline \multirow{46}{*}{ Passeriformes } & Acrocephalidae & African yellow warbler & Iduna natalensis & LC \\
\hline & & Eastern olivaceous warbler ${ }^{\uparrow}$ & Iduna pallida & $\mathrm{LC}$ \\
\hline & Alaudidae & Thekla lark & Galerida theklae & $\mathrm{LC}$ \\
\hline & & Rufous rumped lark* & Pinarocorys erythropygia & $\mathrm{LC}$ \\
\hline & & Black crowned sparrow lark & Eremopterix nigriceps & $\mathrm{LC}$ \\
\hline & Buphagidae & Red-billed oxpecker & Buphagus erythrorhynchus & $\mathrm{LC}$ \\
\hline & & Yellow-billed oxpecker & Buphagus africanus & $\mathrm{LC}$ \\
\hline & Emberizidae & Cinnamon breasted bunting & Emberiza tahapisi & LC \\
\hline & & Golden breasted bunting & Emberiza flaviventris & LC \\
\hline & Estrildidae & Red-billed firefinch & Lagonosticta senegala & $\mathrm{LC}$ \\
\hline & & Red-cheeked cordonbleu & Uraeginthus bengalus & LC \\
\hline & & Southern cordonbleu & Uraeginthus angolensis & $\mathrm{LC}$ \\
\hline & & Yellow-billed waxbill & Coccopygia quartinia & $\mathrm{LC}$ \\
\hline & & Fawn-breasted waxbill & Estrilda paludicola & $\mathrm{LC}$ \\
\hline & & Common waxbill & Estrilda astrild & $\mathrm{LC}$ \\
\hline & & Bronze mannikin & Lonchura cucullata & LC \\
\hline & & African silver bill & Eudica cantans & LC \\
\hline & & Black-rumped waxbill & Estrildida troglodytes & $\mathrm{LC}$ \\
\hline & Hirundinidae & Ethiopian swallow & Hirundo aethiopica & $\mathrm{LC}$ \\
\hline & & Wire-tailed swallow & Hirundi smithii & $\mathrm{LC}$ \\
\hline & Laniidae & Lesser grey shrike & Lanius minor & $\mathrm{LC}$ \\
\hline & & Red-backed shrike & Lanius collurio & $\mathrm{LC}$ \\
\hline & & Woodchat shrike & Lanius senator & $\mathrm{LC}$ \\
\hline & & Masked shrike & Lanius nubicus & $\mathrm{LC}$ \\
\hline & Leiothrichidae & White-headed babbler & Turdoides leucocephala & $\mathrm{LC}$ \\
\hline & Malaconotidae & Black-headed gonolek & Laniarius erythrogaster & $\mathrm{LC}$ \\
\hline & & Northern puffback & Dryoscopus gambensis & LC \\
\hline & & Ethiopian boubou & Laniarius aethiopicus & $\mathrm{LC}$ \\
\hline & Monarchidae & African paradise flycatcher & Terpsiphone viridis & LC \\
\hline & Motacillidae & Western yellow wagtail ${ }^{\wedge}$ & Motacilla flava & LC \\
\hline & & White wagtail ${ }^{0}$ & Motacilla alba & LC \\
\hline & & African pied wagtail & Motacilla aguimp & $\mathrm{LC}$ \\
\hline & Muscicapidae & Common rock thrush & Monticola saxatilis & $\mathrm{LC}$ \\
\hline & & Black scrub robin & Cercotrichas podobe & LC \\
\hline & & Northern wheatear & Oenanthe oenanthe & $\mathrm{LC}$ \\
\hline & & Pied wheatear ${ }^{\wedge}$ & Oenanthe pleschanka & $\mathrm{LC}$ \\
\hline & & Mocking cliff chat & Thamnolaea cinamomeiventris & $\mathrm{LC}$ \\
\hline & Nectariniidae & Scarlet-chested sunbird & Chalcomaitra senegalensis & $\mathrm{LC}$ \\
\hline & & Mariqua sunbird & Cinnyris mariquiensis & $\mathrm{LC}$ \\
\hline & & Malachite sunbird & Nectarinia famosa & $\mathrm{LC}$ \\
\hline & & Shining sunbird & Cinnyris habessinicus & $\mathrm{LC}$ \\
\hline & & Black-billed sunbird & Cinnyris nectarinioides & LC \\
\hline & Passeridae & Northern grey-headed sparrow & Passer griseus & $\mathrm{LC}$ \\
\hline & & Shelley's rufous sparrow & Passer shelleyi & LC \\
\hline & Ploceidae & Black-headed weaver & Ploceus melanocephalus & LC \\
\hline & & Northern-red bishop & Euplectes nigroventris & LC \\
\hline
\end{tabular}


TABle 1: Continued.

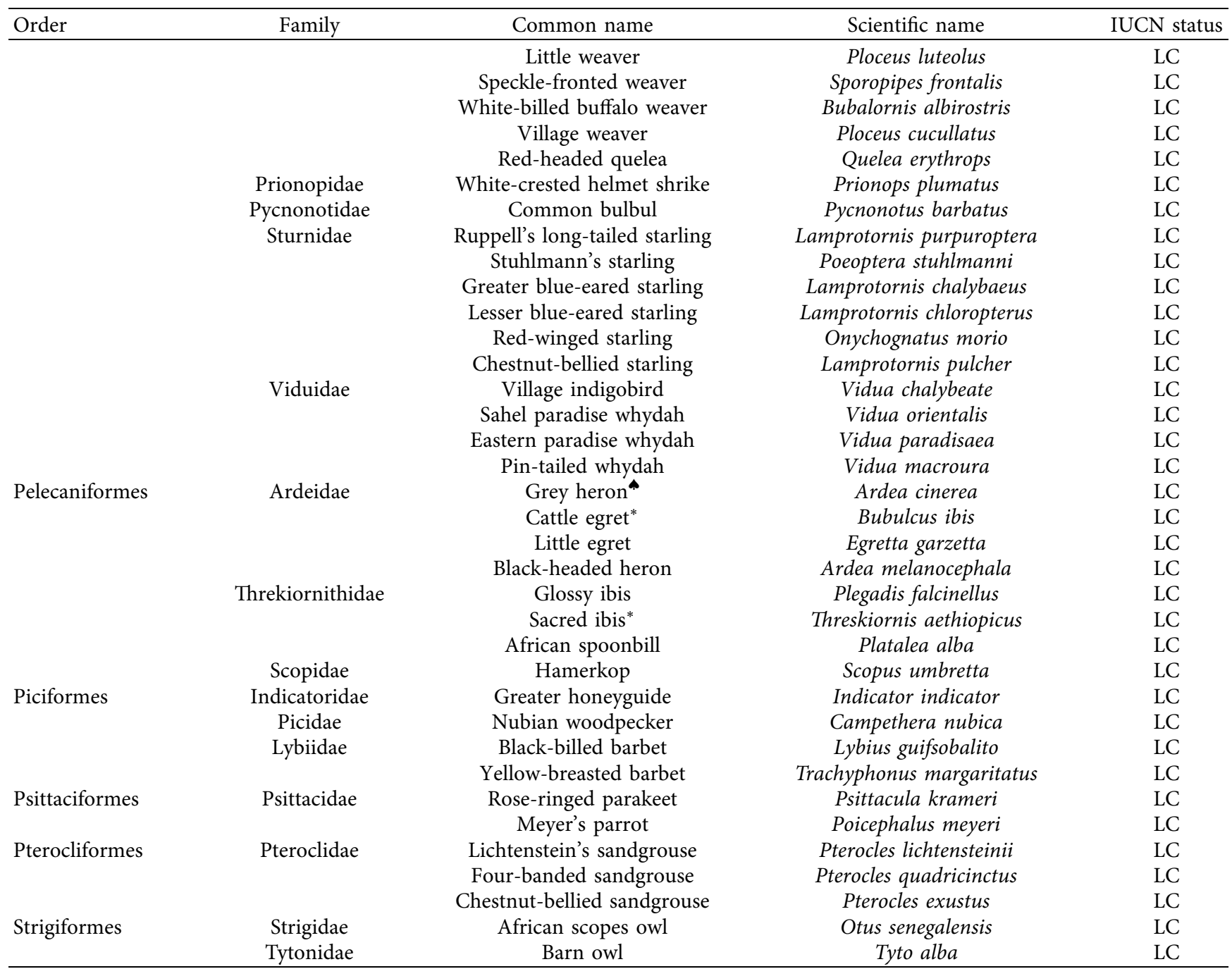

Note. $\mathbf{\uparrow}=$ Palaearctic migrant, $*=$ Intra-African migrant, $\boldsymbol{\varphi}=$ partial migrant, unmarked species are resident birds, LC = least concern, NT =near threatened, $\mathrm{VU}=$ vulnerable, $\mathrm{EN}=$ endangered, and $\mathrm{CR}=$ critically endangered.

other parts of Ethiopia [22-25]. Changes in vegetation composition and structure of habitat complexity and suitability, a change over the time, affect bird species composition [26]. Kafta Sheraro National Park is a home for 15.8\%, $5.7 \%$, and $1.9 \%$ Palaearctic migrants (PM), Intra-African migrants (IM), and partial migrants, respectively. This revealed that the park is very important for migratory bird species in addition to sedentary birds.

Higher diversity of index was recorded during February $\left(H^{\prime}=4.50\right)$ followed by January $\left(H^{\prime}=4.15\right)$ and August $\left(H^{\prime}=4.05\right)$ while the lowest diversity index was recorded during March and October with $\left(H^{\prime}=2.18\right.$ and $\left.H^{\prime}=3.47\right)$, respectively. This showed that both species richness and evenness were high during February, January, and August. In ecological studies, the Shannon-Weiner diversity index is greater than 4 as both the richness and the evenness of the community have increased [27]. The difference in avian diversity among the study months might be associated with the availability of the food source among the months and the effect of migratory bird species. The availability of resources, especially plenty food supply, may increase the diversity of avian species at a given area [24]. The highest and lowest number of species $(S)$ was recorded during January and October with $83 \%$ and $68 \%$ species, respectively. The high number of bird richness in January may be due to the migratory birds which migrate to the park from different directions of the globe. Bird species are migrating to Kafta Sheraro National Park for feeding during the winter. The researchers observed that there were migratory birds that arrive in the park starting from January and leave at the end of April. The lowest number of bird species during October might be due to temporary migration of bird species from the park to the nearest agricultural fields that provide alternative temporary seasonal foraging and nesting opportunities to the birds. This could decrease their abundance in their natural habitat [15]. The diversity index result showed that the species diversity during the wet season was higher than the dry season. This might be due to the presence of 


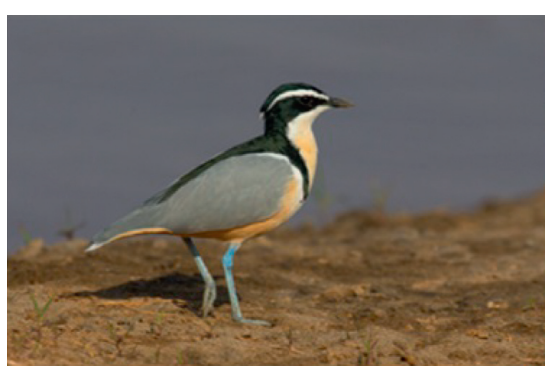

(a)

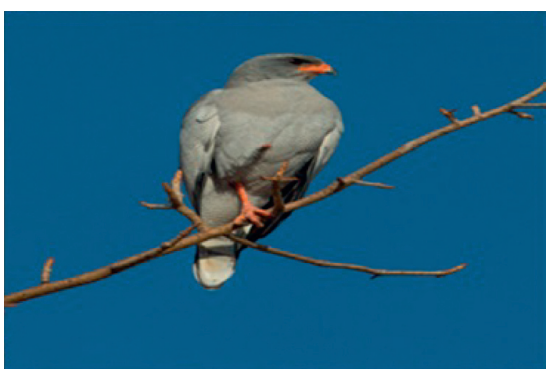

(d)

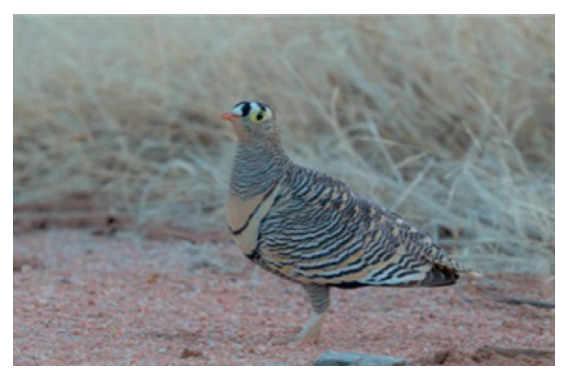

(b)

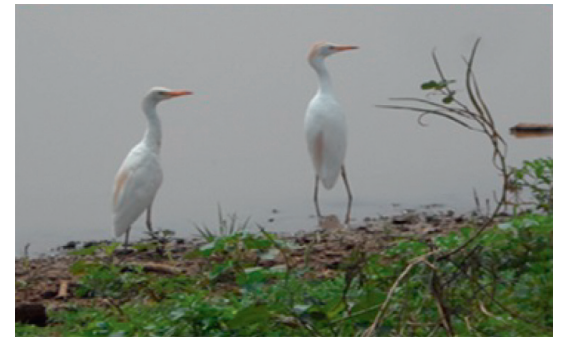

(e)

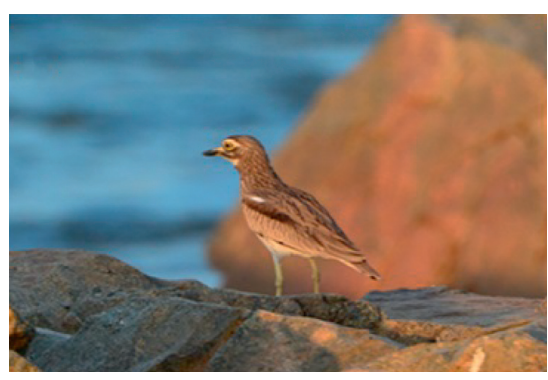

(c)

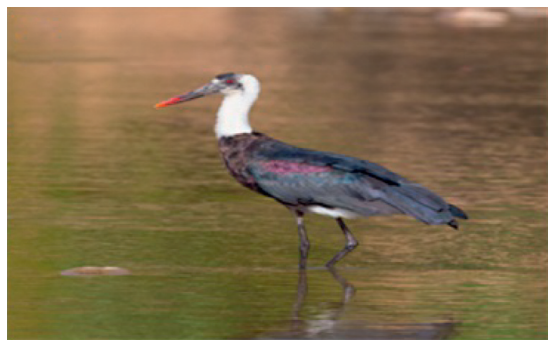

(f)

Figure 2: Few attractive bird species located in KSNP. (a) Pluvianus aegyptius. (b) Pterocles lichtensteinii. (c) Burhinus senegalensis. (d) Micronisus gabar. (e) Bubulcus ibis. (f) Ciconia episcopus.

TABLE 2: Species richness, species evenness, and species diversity among the study months.

\begin{tabular}{lcccc}
\hline Months & Species richness & $H^{\prime}$ & $H_{\max }^{\prime}$ & $E$ \\
\hline August & 97 & 4.05 & 4.57 & 0.88 \\
September & 100 & 3.74 & 4.60 & 0.81 \\
October & 92 & 3.47 & 4.52 & 0.76 \\
January & 131 & 4.15 & 4.87 & 0.85 \\
February & 96 & 4.50 & 4.56 & 0.98 \\
March & 108 & 2.18 & 4.68 & 0.46 \\
\hline
\end{tabular}

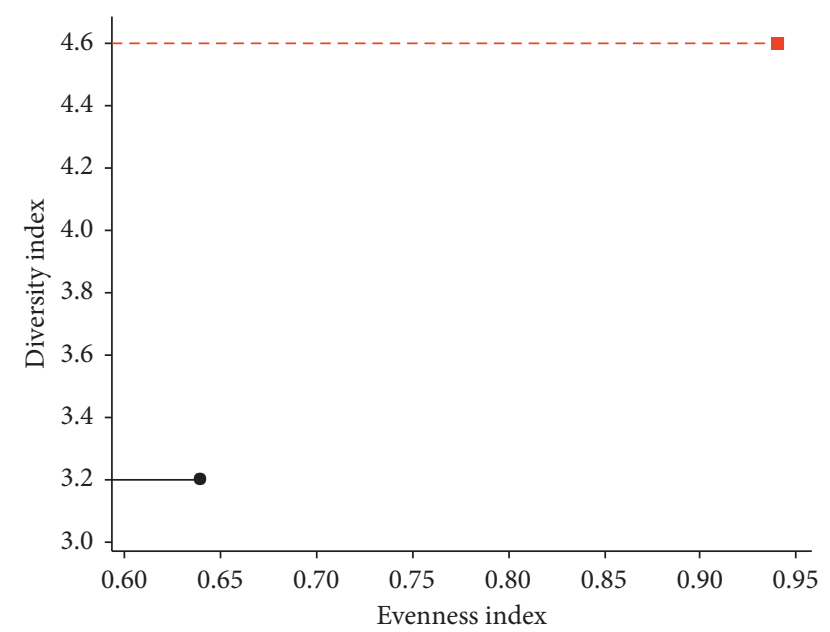

Seasons

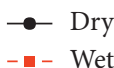

FIGURE 3: Seasonal diversity and evenness index of bird species. food sources in the park. During the wet season, the productivity and yield of habitat increase as many of the invertebrates breed and the vegetation becomes more productive on which the birds depend, and as a result, the diversity increases.

The result of this study also showed that the park faced with five major threats such as expansion of agriculture, fire, grazing, mining, and hunting. Expansion of agricultural fields in and in close of vicinity of the park was causing much severe to avifauna by creating disturbances. Moreover, irrigation was the main farming activity along the edge of Tekeze River. These agricultural activities absolutely had an impact on the habitat of the bird species. A study conducted on human wildlife conflict witnessed that fire, cutting trees, poaching, and farmland were the main anthropogenic impacts for biodiversity of Kafta Sheraro National Park [28]. Similar challenges were reported in other study area which is in Awash National Park [29]. Fire was a common threat of Kafta Sheraro National Park that affects feeding and resting places or times of bird species. The scouts revealed that fire in the national park was caused by people who pick up minerals illegally from the park. Wildfire is becoming a very serious problem in Kafta Sheraro National Park, destroying thousands of hectares of the park each year [30]. The local communities brought their cattle into the national park for searching of grazing land and water especially during the dry season. This created interruption in activities of the birds. Mining activity in the park also affected bird species negatively by destructing their habitat. Illegal gold mining was challenging in Kafta Sheraro National Park. Habitat disturbances by humans have varying effects on the bird species richness and diversity. As human pressure increases, the quality of the forests to harbor different bird species reduces 
[31]. Habitat disturbance negatively affects avian diversity and abundance [26]. As the discussion made with the local people who were living near the park forwarded, the local community developed a negative attitude towards the establishment of the park. This is because of the fact that they believe that the area is core for agriculture, irrigation, livestock grazing, and mining. Therefore, they believe that the park is going to make them lose these things.

\section{Bird Species of Conservation Concern}

In the current study, seven globally threatened bird species were recorded in the park. Hooded vulture (CR), African white-backed vulture (CR), lappet-faced vulture (EN), steppe eagle (EN), tawny eagle (VU), Abyssinian ground hornbill (VU), and woolly-necked stork (VU) were bird species of conservation concern in this study area. These bird species were suffered as a result of destruction of their habitat, breeding site, and food source due to anthropogenic activities including agricultural expansion, fire, mining, and grazing. It is therefore very important to take measures toward conserving the threatened bird species.

5.1. Hooded Vulture (Necrosyrtes monachus). Hooded vulture is native to sub-Saharan Africa. A study indicated that the population is extremely rapid declining due to poisoning, trade for traditional medicine, hunting, persecution, and electrocution, habitat loss, and degradation [32]. Other study conducted in Dakar, Senegal, indicated that hooded vulture has been declining due to exponential urbanization resulting in loss of feeding sites and reduced food availability, increased poisoning of feral dogs with strychnine sulphate due to an upsurge of rabies, and increased disappearance of suitable trees for nesting and roosting [33]. In the current study area, habitat loss and degradation were the main threats for the bird species.

5.2. African White-Backed Vulture (Gyps africanus). The African white-backed vulture is widespread across the savannahs of Africa occurring from South Africa north to Ethiopia and west to Senegal. This species has declined severely in parts of its range. Habitat loss, hunting for trade, persecution, collisions, and poisoning were the main threats of this species. These declines are likely to continue into the future [34].

5.3. Lappet-Faced Vulture (Torgos tracheliotos). The total population of lappet-faced vulture is estimated to be declining at a very rapid rate. According to Ogada et al. [35], the population of lappet-faced vulture in Africa was declining by $80 \%$ over three generations. The species are at high risk due to pesticides and poisoning. Lappet-faced vulture is regionally extinct from North Africa, Israel, Jordan, and Palestinian territory [36].

5.4. Steppe Eagle (Aquila nipalensis). As steppe eagle is a long-distance migrant bird, it exposed to varying levels of environmental and anthropic pressures such as drought, habitat destruction, or illegal hunting. Habitat loss, human persecution, and electrocution on power lines are also potential threats of the species throughout its range. Its current population status is extremely declining [37].

5.5. Tawny Eagle (Aquila rapax). Although Aquila rapax is a widespread raptor occurring over large areas of sub-Saharan Africa, with isolated populations in North Africa, the Middle East, and South Asia, the species is rapid declining from across its African range including the current study area. In this study, habitat destruction due to agricultural expansion, fire, and mining was the main threat for the bird species.

5.6. Abyssinian Ground Hornbill (Bucorvus abyssinicus). The Abyssinian ground hornbill ranges through subSaharan African savannahs north of the equator. Even though determining conservation status of this species is very difficult due to the lack of research, this species is suspected to be declining rapidly as a result of habitat loss and degradation and hunting for traditional medicine [32].

5.7. Woolly-Necked Stork (Ciconia episcopus). This species is undergoing a rapid population decline mainly due to pollution, habitat loss, and persecution. Its population status in the current study was also observed in few individuals.

\section{Conclusion}

The result of this project showed that Kafta Sheraro National Park is one of the areas which has high avian diversity in Ethiopia. Hence, it is concluded that the park has a good potential for ornithological tourism that can integrate economic gain with biodiversity conservation. Specific conclusion on the diversity and composition of bird species might not be possible due to lack of published data that describe bird species prior to the current study in the park. Based on direct observation and discussion made with local communities and scouts, fire, agricultural activity, mining, grazing, and hunting were the major threats that affected bird species diversity and abundance in the park. The current study also identified that the local community developed a negative attitude toward the park.

As the park harbors high number of attractive bird species, ecotourism of the park through wildlife watching in general and ornithological tourism in particular should be developed by collaborating with stakeholders. The number of bird species recorded in this study may not represent all the bird species that are present in Kafta Sheraro National Park. Therefore, exhaustive survey should have been made in all the habitats by increasing the length of the study period and the sampling area. Continuous efforts should also be made on minimizing the anthropogenic disturbances by controlling the activities that take place inside the national park such as fire, deforestation for agricultural activities, and mining. Organization of awareness creation programmes for the local community may also help to develop a positive 
attitude towards the park to reduce the potential threats on avifauna.

\section{Data Availability}

The data used to support the findings of this research are available from the corresponding author upon request.

\section{Conflicts of Interest}

The authors declare that they have no conflicts of interest.

\section{Authors' Contributions}

The corresponding author, TG, had taken responsibilities of the proposal drafting, data collection, and writing up of the manuscript. The other authors participated in data collection, data analysis, identifying of bird species, and commenting on the proposal and manuscript. All authors read and approved the final manuscript.

\section{Acknowledgments}

The authors thank the office of Kafta Sheraro National Park for permitting them the vehicle. They also thank all staffs of Kafta Sheraro National Park for creating a homely working environment and their unlimited friendly relationship during the field investigations they had in the park. Adigrat University provided the fund of this research for the data collection with registration number (AGU/CNCS/018/09).

\section{References}

[1] D. Vreugdenhil, A. M. Vreugdenhil, T. Tamirat, S. Anteneh, and T. Zelealem, Gap Analysis of the Protected Areas System of Ethiopia, with Technical Contributions from L. Nagelkerke, K. Gedeon, S. Spawls, D. Yalden, L. Berhanu, L. Siege, World Institute for Conservation and Environment, Shepherds, VA, USA, 2012.

[2] D. Lepage, "Bird checklists of the Ethiopia, bird life international," 2018, http://www.bsceoc.org/avibase.2018.

[3] EBI (Ethiopian Biodiversity Institute), Ethiopia's Fifth $\mathrm{Na}$ tional Report to the Convention on Biological Diversity, Ethiopian Biodiversity Institute, Addis Ababa, Ethiopia, 2014.

[4] S. Rajashekara and G. M. Venkatesha, "Community composition of aquatic birds in lakes of Bangalore," Journal of Environmental Biology, vol. 32, pp. 77-83, 2011.

[5] M. Colwell, "The Church in the forest," Conservation in Ethiopia, vol. 18, no. 2, 2010.

[6] C. Sinha, "Wildlife tourism: a geographical perspective," in Proceedings of the Geography Curriculum Inservice Conference, London, UK, January 2001.

[7] World Tourism Organization (WTO), World Tourism Organization Towards Measuring the Economic Value of Wildlife Watching Tourism in Africa-Briefing Paper, UNWTO, Madrid, Spain, 2014.

[8] A. Nicolaides, "Stakeholders, purposes and responsibilities: avitourism in South Africa," African Journal of Hospitality Tourism and Leisure, vol. 3, pp. 1-14, 2014.

[9] J. Palacio-Nunez, R. J. Verdu, E. Galante, D. Jimenez-Garcia, and G. Olmos-Oropeza, "Birds and fish as bioindicators of tourist disturbance in springs in semi-arid regions in Mexico: a basis for management," Animal Biodiversity and Conservation, vol. 3, pp. 29-41, 2007.

[10] J. Shoshani and D. Yirmed, "Report on the Kafta-Sheraro National Park," in memorial to Professor Jeheskel Shoshani. Tigray Region, Ethiopia. S. K. Sikes.1971. The African elephant and its natural community life, pp. 256-285, The Trinity Press, London, UK, 2008.

[11] G. Berihun, D. Yirmed, A. Teshale, and M. Berhane, "Notable records of wintering site of the Demoiselle crane (Anthropoides virgo) in Kafta-Sheraro National Park, Ethiopia," African Cranes, Wetlands and Communities Newsletter, vol. 5, pp. 9-15, 2009.

[12] W. J. Sutherland, Ecological Census Techniques: A Hand Book, Cambridge University Press, Cambridge, UK, 1996.

[13] C. J. Redman, M. Johnes, and S. Marsden, "Expedition field techniques: bird surveys," Expedition Advisory Centre of the Royal Geographical Society, vol. 1, pp. 134-137, 2009.

[14] M. P. Vergara, E. J. Jiménez, and P. R. Schlatter, "Effective point-count duration for estimating bird species' richness in Chilean forests," Zoological Studies, vol. 49, pp. 381-391, 2010.

[15] A. Shimelis and B. Afework, "Species composition, relative abundance and distribution of bird fauna of riverine and wetland habitats of Infranz and Yiganda at Southern tip of Lake Tana, Ethiopia," Tropical Ecology, vol. 49, pp. 199-209, 2008.

[16] A. Hailemariam, Y. Meheretu, and H. H. Tsegazeabe, "Community composition and abundance of residential birds in selected church forests, Tigray Region, Northern Ethiopia," Scientific Research and Essays, vol. 8, pp. 1038-1047, 2013.

[17] T. Stevenson and J. Fanshawe, Birds of East Africa: Field Guide, Christopher Helm Black Publishers, Ltd., London, UK, 2002.

[18] B. V. Perlo, Birds of Eastern Africa, Collins Field Guide, Harper Collins Publisher, Hong Kong, China, 2009.

[19] R. N. Stevenson and T. Fanshawe, Helm Field Guides to the Birds of Horn of Africa, Ethiopia, Eritrea, Djibouti, Somalia and Socotra, Christopher Helm, London, UK, 2009.

[20] C. E. Shannon and N. Wiener, The Mathematical Theory of Communication, The University of Illinois press, Champaign, IL, USA, 1949.

[21] A. Kathleen, K. Nolan, and J. E. Callahan, "The ShannonWeiner species diversity index," Beachcomber Biology, vol. 27, pp. 334-338, 2005.

[22] A. Shimelis and B. Afework, "Species composition, relative abundance and habitat association of the bird fauna of the Montane forest of Zegie Peninsula and nearby islands, Lake Tana, Ethiopia," SINET: Ethiopian Journal of Science, vol. 32, no. 1, pp. 45-56, 2009.

[23] Z. Girma, G. T. Mengesha, and T. Asfaw, "Diversity, relative abundance and distribution of Avian fauna in and around Wondo Genet forest, South-Central Ethiopia," Research Journal of Forestry, vol. 11, no. 1, pp. 1-12, 2017.

[24] E. Kalkidan and B. Afework, "Species composition, relative abundance and distribution of the avian fauna of Entoto Natural Park and escarpment, Addis Ababa," SINET: Ethiopian Journal of Science, vol. 34, no. 2, pp. 113-122, 2011.

[25] T. Megersa, G. Tsegaye, and G. Gelaye, "Avian diversity in Dhati Walel National Park of Western Ethiopia," International Journal of Molecular Evolution and Biodiversity, vol. 6, pp. 1-12, 2016.

[26] A. Assefa, A. B. Davies, A. E. McKechnie, A. A. Kinahan, and B. J. Ransburg, "Effects of anthropogenic disturbance on bird diversity in Ethiopian montane forests," The Condor: Ornithological Applications, vol. 119, no. 3, pp. 416-430, 2017. 
[27] A. E. Magurran, Measuring Biological Diversity, Blackwell, Oxford, UK, 2004.

[28] B. Atakilt, Y. Gidey, and T. Gebregizabher, "Human-wildlife conflict in Kafta-Sheraro National Park, Northern Ethiopia," World Journal of Zoology, vol. 11, pp. 154-159, 2016.

[29] T. Binayew and A. Yiheyis, "Sustainable ecotourism potentials and its challenges in Ethiopia: the Awash national park in focus," International Journal of Humanities and Social Science Research, vol. 2, pp. 41-49, 2016.

[30] M. Dawit, "Causes of wild fire assessment in Kafta Sheraro national park, Tigray, Ethiopia," Global Journal of Agricultural Research, vol. 2, no. 1, pp. 66-70, 2014.

[31] S. N. Hassan, A. R. Salum, A. A. Rija et al., "Human-induced disturbances influence on bird communities of coastal forests in Eastern Tanzania," British Journal of Applied Science \& Technology, vol. 3, no. 1, pp. 48-64, 2013.

[32] V. L. Williams, A. B. Cunningham, A. C. Kemp, and R. K. Bruyns, "Risks to birds traded for african traditional medicine: a quantitative assessment," PLoS One, vol. 9, no. 8, Article ID e105397, 2014

[33] W. C. Mullié, F. X. Couzi, M. S. Diop et al., "The decline of an urban Hooded Vulture Necrosyrtes monachus population in Dakar, Senegal, over 50 years," Ostrich, vol. 88, no. 2, pp. 131-138, 2017.

[34] W. L. Phipps, S. G. Willis, K. Wolter, and V. Naidoo, "Foraging ranges of immature african white-backed vultures (Gyps africanus) and their use of protected areas in Southern Africa," PLoS One, vol. 8, no. 1, Article ID e52813, 2013.

[35] D. Ogada, P. Shaw, R. L. Beyers et al., "Another continental vulture crisis: africa's vultures collapsing toward extinction," Conservation Letters, vol. 9, no. 2, pp. 89-97, 2016.

[36] BirdLife International, Torgos Tracheliotos: The IUCN Red List of Threatened Species, BirdLife International, Cambridge, UK, 2017.

[37] B. Meyburg, C. Meyburg, and P. Paillat, "Steppe Eagle migration strategies-revealed by satellite telemetry," British Birds, vol. 105, pp. 506-519, 2012. 